\title{
The Return to the Social through the Collective "I": Disrupting the Uneventful Face of Neoliberal Precariousness in the Chilean Documentary El otro día
}

\section{Walescka Pino-Ojeda}

To cite this article: Walescka Pino-Ojeda (2017) The Return to the Social through the Collective "I": Disrupting the Uneventful Face of Neoliberal Precariousness in the Chilean Documentary El otro día, Critical Arts, 31:5, 28-44, DOI: 10.1080/02560046.2017.1405054

To link to this article: https://doi.org/10.1080/02560046.2017.1405054

曲 Published online: 07 Feb 2018.

Submit your article to this journal ¿

LII Article views: 6

Q View related articles ¿

View Crossmark data $\nearrow$ 


\title{
THE RETURN TO THE SOCIAL THROUGH \\ THE COLLECTIVE "I": DISRUPTING THE UNEVENTFUL FACE OF NEOLIBERAL PRECARIOUSNESS IN THE CHILEAN DOCUMENTARY EL OTRO DÍA
}

\author{
Walescka Pino-Ojeda \\ https://orcid.org/0000-0001-7036-8845 \\ University of Auckland, New Zealand \\ w.pino-ojeda@auckland.ac.nz
}

\section{ABSTRACT}

Produced 21 years after the return to institutional democracy in Chile, Ignacio Agüero's El otro día (The other day, 2012) picks up a set of social topics that were left in suspension under authoritarianism. In doing so, it evidences two main divergences in this renewal of social projects. Firstly, rather than adopting old hierarchies of detached narration, this film adopts a contemplative, self-referential first-person perspective. Secondly, it frames the encounter with the social-not in a depiction of public space, but in the secluded, private space of domesticity and family life, hence marking a fundamental difference from the monumental autobiographical voice that still defines the first-person subject in the modernist artistic tradition. Following Deleuze's theory of the time-image (Cinema II: The Time-Image. London: Continuum, 2005), it is suggested that El otro dia demonumentalises the positioning of the artist through intimacy, and through the use of a contemplative form of narration that actualises the uneventful face of neoliberal poverty, thus constructing a social critique in which action is subordinated to time rather than to movement. Picking up on the concept "singular plural", it is proposed that what takes place in this film is a "collective I", this in order to emphasise Chilean documentary's own tradition within the legacy imprinted by authoritarianism.

Keywords: Chilean documentary; memory; neoliberalism; popular social subject; collective "I"; time-image

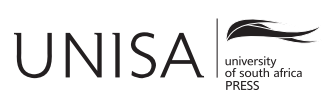

Critical Arts

Volume 31 | Number 5 | 2017 | pp. 28-44

www.tandfonline.com/rcrc20

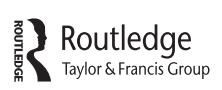

Taylor \& Francis Group

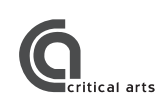

https://doi.org/10.1080/02560046.2017.1405054 ISSN 1992-6049 (Online), ISSN 0256-0046 (Print)

(C) Unisa Press 2017 


\section{POVERTY, TRAUMA, AND PRECARIOUSNESS}

Social critique has been a dominant concern in Chilean documentary since the 1950s, when experimental film schools in universities first identified specific social priorities in an aesthetic language that still generally defines Chilean documentary film. Although the military coup radically ruptured this trajectory, the film schools' selection of social issues, especially poverty, continued to be timidly raised even under dictatorship (Vega 2006,40 ), and the major issue of human rights violations was added a bit later. This history explains the move by Chilean film toward forms of documentation designed to both leave a record and, above all, denounce injustice, making it the essential medium used by the surviving victims and their families to leave their testimony to atrocities committed under dictatorship.

This turn toward the voice of the victims and eyewitnesses provides a place for what I have elsewhere described as the documentary of forensic memory (Pino-Ojeda 2013). What stands out in these films is a mimetic exposition in which the documentarian assumes the voice of a committed, involved "witness" and locates him- or herself alongside the witnessing victims, yet takes care to ensure that such closeness does not threaten the ethical and unique place occupied by the authentic victims of the atrocity. This is a voice that is therefore qualitatively different to that of the third person, which had been dominant in documentary up to that point.

In the documentary El otro dia (The other day, 2012), produced 21 years after the return to institutional democracy in Chile, Ignacio Agüero reconnects with the social concerns that had been suspended under authoritarianism as it subsequently developed, through the documentary of memory. ${ }^{1}$ There are, however, two main differences I observe in this renewed return to the social: first, instead of resorting to the old distanced and hierarchical voice, the film turns toward the first person and assumes a narrative mode using a contemplative rhythm that seems to "construct" a slowdown, created through fixed shots in a kind of "photography in movement"" (De los Ríos and Donoso $2015,73)$. This autobiographical voice is further strengthened when the documentarian chooses the privacy of his own home to convey his thoughts and memories. ${ }^{2}$ The encounter with the social here is not constructed from the public space, where the filmmaker's focus on collective subjects had previously constructed a simulacrum of an objective voice through which the popular subject became transparent. Instead, his approach to the social is created from the secluded, private space of the domesticity of family life. This shift from the agora to the cloister is what also marks its difference from the monumental autobiographical voice that still defines the first-person subject in

1 Ignacio Agüero (born 1952, Chile) has made 14 documentaries to date, starting in 1972 with Hoy es jueves cinematográfico (Today is cinematographic Thursday), with the most recent being Como me da la gana II (How I feel like it II, 2016). For a full trajectory on his filmography, see De los Ríos and Donoso (2015).

2 For an analysis of the proliferation of autobiographical documentaries in Chile, see Bossy and Vergara (2010), Escobar Arellano (2012), and Santa Cruz (n.d.). 
the modernist artistic tradition. Instead, I maintain that the autobiographical voice in $E l$ otro dia demonumentalises the individual voice of the artist through an intimate story, constantly interrupted by third parties, a voice that I believe is the result of work done by the documentary of memory.

The second aspect distinguishing social reality in El otro dia from what had been the norm in the pre-authoritarian era is its focus on the everyday. Documentary filmmaking from the 1950 s to the 1970 s attempted to capture the popular social subjectin-the-making during the era of the committed, responsible state ("el Estado de compromiso"). All of this conferred on the documentary of that era a foundational stamp that both exhibited and promoted the effervescence of the developmentalist impulse while denouncing exclusion and exploitation, exposed through overwhelming poverty. This process explains how documentary participates from the aesthetic realm in the macro-transformations and projects of the era. The space occupied by documentary in the second millennium is very different. Today what prevails is a neoliberal state that has renounced its role in directing a national project. This is why the state's former leadership and public responsibility has given way to the corporate world, with its entrepreneurs having now become the great protagonists of the new national project, a place formerly occupied by the popular social subject. The macro-event of social transformation that was taking place in the public arena has been replaced by individualised projects. Hence, the foundational monumentality of those bygone days has given way to a minimalist triviality of the everyday, in which poverty has become invisible and what is normalised is accumulation by dispossession (Harvey 2005, 159).

Given the social framework created by authoritarianism and its imposition of the neoliberal socio-economic model, in what way can new forms of social unease be presented and given coherent visibility? Are the methods and forms of 1950s-1970s documentary film-making able to represent these new modes of social abuse and suffering? Following Deleuze's (2005b) theory of the time-image, I suggest that in $E l$ otro día Agüero's use of a laconic and contemplative form of narration actualises these new forms of precarity, normalised and obfuscated by the uneventful appearance of neoliberal poverty. Thus, social critique is constructed by emphasising the ways in which action is subordinated to time rather than to movement. For Deleuze, the shift from movement-image to time-image is a consequence of the schism produced by the Second World War: "Everything perhaps suddenly appears in a shattering of the sensory-motor schema: this schema, which has linked perceptions, affections and actions, does not enter a profound crisis without the general regime of the image being changed" (2005a, xxii). This approach is certainly applicable to the social and psychological fracture produced by the authoritarian regimes that plagued South America in the 1970s and 1980s. In said context, we bear witness to a violence activated by state terror, which has inevitably altered the gaze and voice later developed by documentary films of memory, and which likewise has influenced the manner in which social themes are being readdressed today.

However, this focus on the time-image observed in El otro dia also lends itself to analysing the new forms of experiencing and assuming time created by the society of 
consumption, which Ulrich Beck and Elizabeth Beck-Gernsheim (2000) describe as the movement from the reflexive to the "reflective" (reflective acts), and their evident impact on the appreciation that subjects are able to create about their own identity and the site they occupy in the community to which they feel they belong.

\section{FROM THE POPULAR SOCIAL SUBJECT ${ }^{3}$ TO THE COLLECTIVE "I"}

Explaining this renewed focus on the social as exposed in El otro dia requires an account of the historical-political trajectory and resulting aesthetic transformations it brought into Chilean documentary. We should begin by recalling that experimental university documentary film-making (1957-1973) ${ }^{4}$ was developed as an alternative to the emergent commercial fiction film, with its emphasis on the successful exploits of heroes. This new form of documentary also distanced itself from the publicity documentary promoted by the state and private enterprise, which was focused on strengthening industrialisation in the country (Corro et al. 2007, 8-9 and 78-79). University documentary was critically located in this context, where none of the other social languages were meaningfully placed: in the margins and cracks ignored or not reached by the modernising impetus of the state. Therefore, although critical in its own aesthetic language, the university documentary that was produced from 1957 to the military coup d'état in 1973 actively participated in the state programme. This is clear in the work of the Film Institute at Universidad Católica de Chile (the Catholic University of Chile) and the Experimental Film Institute of Universidad de Chile (the University of Chile).

This documentary work was possible because of the humanist goals that defined public programmes of the era, and although modest in its early stages, such film still enjoyed the support of both institutions and citizens, as it was directed by mass media that emphasised its social purpose (Salinas Muñoz and Stange Marcus 2008, 28-29; Vega 2006, 17). As the impoverished condition of the working class and marginalised majority became more evident, the official impulse for change gradually became part of cinematographic aesthetics attempting to revolutionise society by establishing a new system with new actors, particularly those situated at the energetic centre of developmentalism: organised workers, campesinos (peasants), students, and all those agents aware of their central role in the national project. It is this collective consciousness and organisation that gives birth to the popular social subject. Paradoxically, the documentary aesthetics of the era promoted the pre-eminence of a distanced voiceincluding the "voice of God", "the poetic mode", and "observational" and "participatory

3 A full definition of the "popular social subject" in the Chilean context is provided by Salazar and Pinto $(1999,96)$.

4 I am referring to the Film Institute at Universidad Católica de Chile (the Catholic University of Chile), created in 1955, and the Experimental Film Institute of Universidad de Chile (the University of Chile), founded in 1957. Both were closed after the coup d'état of September 11, 1973. For further details, see Vega $(2006,16)$ and Corro et al. $(2007,11)$. 
modes" (Nichols 2001) - fully aware of the socio-economic and cultural gap between the artist and the subjects documented. Nonetheless, the ethical climate in which this took place still normalised the need to bridge these distances, hierarchies, and exclusions. The dialogue and similarities between New Chilean Cinema-whose greatest production was reached during the rule of the Unidad Popular (September 1970 to September 1973), with the release of 40 documentaries in contrast to the 36 produced over the next 17 years of the dictatorship (Vega 2006, 40) - and film developing in other countries of the region form part of New Latin American Cinema.

Authoritarianism not only cut short the social, ethical, and aesthetic process that was taking place, it also established an insurmountable rupture: many audiovisual artists suffered persecution, torture, and death, while others were forced into exile. Both university institutes mentioned above were closed. The state terror imposed by the dictatorship controlled all institutions, including universities and the mass media, and it would gradually occupy even the emotional and psychological life of citizens, producing the isolation and breakdown of social and affective relations that up to that time were being healed and strengthened. Documentarians who remained in the country felt as though they had been left orphaned, since, in addition to the abovementioned, they were not able to use the aesthetic language created and handed down to them by their predecessors, as it was now targeted as part of the culture and value system that was prohibited.

It is within this context that we may situate another of Agüero's films, No olvidar (Don't Forget, 1982), the first film to chronicle human rights abuses perpetrated by the Chilean military regime. Moreover, after nine years of dictatorship, from an aesthetic and ethical viewpoint, No olvidar initiates a double role played by traumatic memory in Chilean documentary cinema of the authoritarian era, as it also does with the majority of post-dictatorship period film. Traumatic memory is located simultaneously at the thematic epicentre and in the discursive pathway; it is the fissure from which the atrocities perpetrated by the military government are expressed, recorded, and purged. From this positioning, the ethical imperative "to not forget" was implemented.

This approach is tenaciously reaffirmed in Agüero's later film, El diario de Agustín (Agustin's Newspaper, 2008), which carries out an investigation into the role played by El Mercurio (a pre-eminent Chilean newspaper) in deliberately destabilising Salvador Allende's administration and supporting the subsequent campaign of terror launched by the dictatorship in order to maintain its power. Here Agüero returns to the agenda he had begun in the thick of the dictatorship, focusing this time on the role played by economic and political elites acting as accomplices to the military regime's abuses. This work is thoroughly supported by the archival research of journalism students at the University of Chile.

Heir to the documentary tradition created by the Film Institute of the Catholic University of Chile, ${ }^{5}$ Agüero and his documentarian contemporaries all adopted the

5 Between 1974 and 1978 Agüero studied at the School of Arts and Communications at the Pontificia Universidad Católica de Chile, the current name of the aforementioned Film Institute. 
customary mode of address, setting themselves apart from their subjects as invisible, objective observers. However, Agüero actually started to break away from this voice in Como me da la gana (How I feel like it, 1985), thus setting the groundwork for the voice he develops in El otro dia. ${ }^{6}$ Picking up on the concept of Jean-Luc Nancy's (1996) "singular plural", recuperated by Alisa Lebow (2012) to analyse the predominance of the first person in recent documentary film, I have decided instead to name this voice "the collective I" to emphasise the intimate relation that this documentary in the autobiographical voice maintains with its own Chilean tradition. At the centre of this local and regional idiosyncrasy is the concept of the "popular social subject", still referred to as "el pueblo" (the people) in the political and sociological language of Latin America. This is different to the other Spanish word for "people", "gente", in that the latter does not indicate the character of the wider social body, organised through its own awareness as a political collective. Here we find a major difference with the definition of the "singular plural" in Nancy's philosophy, which is organised around the concept of "les gens" (the people) as "gente" (Nancy 2000, 7):

"People" clearly designates the mode of "one" by which "I" remove myself, to the point of appearing to forget or neglect the fact that I myself am part of "people". In any case, this setting apart [mise à l'écart] does not occur without the recognition of identity. "People" clearly states that we are all precisely people, that is, indistinctly persons, humans, all of a common "kind," but of a kind that has its existence only as numerous, dispersed, and indeterminate in its generality.

Hence, the political notion of pueblo already alters the ontological meaning of Nancy's gente, which explains why the dictatorship precisely targets this pueblo as an enemy to be eliminated. What is being attacked is the popular social subject rather than individual subjectivities. In this later context, the "people" go from being political agents to subversives, and then slaughtered victims. By facilitating these victims' testimonies, the documentary of memory transmitted a truly shared social pain, a body severely punished by the dictatorial regime. Here the aftermath of terror is documented by a mimetic and empathic voice that not only places us in a position to confront the pain and brokenness of the empowered popular subject of the previous era, but also dislodges the older authorial voice of the distanced documentary narrator.

There is a plethora of analyses that approach the predominance of the autobiographical documentary narrative in the second millennium. ${ }^{7}$ I am inclined to understand this tendency as an indication of the weakening of the documentarian's voice of authority. It surely also falls within Lyotard's (1984) collapse of master narratives, yet I insist that it is better understood in the specific context of the authoritarian regimes of the Southern Cone, which subjected workers, union leaders, artists, intellectuals, students, and politicians

6 I would like to thank the referees for pointing out how as early as 1985 Agüero started to move away from the authoritative and distanced voice, a trend we see fully developed in El otro día.

7 See Piedras (2014), Navarro and Rodríguez (2014), and Arenillas and Lazzara (2016) for a full analysis on this point. 
to the most brutal forms of abuse, regardless of their social class, ethnic background, and profession. As these dictatorships concluded, artists found their perspectives and subjectivities affected in the aftermath of terror, detention, torture, and trauma. Not only was their authority as privileged interpreters and mediators of others' experiences and pain diminished, so too was the existing language of film itself - insufficient, inadequate, unable to capture or represent the horror of the atrocities committed by the dictatorships. The idea of representation in itself had met its limits, and had itself become a problem. Confronted with this new reality, the authority of the documentary's voice is damaged, and the documentary finds itself adopting an agonistic voice that now speaks from the experience of precariousness. It is from this position that a cross-identification process occurs between the respective locations of the documentarian and the psychological and ontological place of the subjects being documented. Therefore, unlike the documentary of social critique of the pre-authoritarian era, the present concern with precariousness takes place within a platform and with an ethical subject produced by the film of memory. For this reason I maintain that, rather than just a subjective turn - as the new-millennium documentary with its autobiographical emphasis has been described - what takes place is an ontological-epistemological turn. Facing an altered and fractured individuality that is aware of being part and result of a sociopolitical whole, the autobiographical subject that emerges is actually responding to a "collective I".

\section{THE TIME-IMAGE: MEMORY AS REFLECTION}

This collective "I", forged from the wound and the synthesis of memory, is demonstrated most clearly in a sequence of scenes in El otro día, threaded around Ignacio Agüero's own father and the motif of the sea. For the first 18 minutes, the viewer is in a house, observing in close detail a number of objects belonging to an educated person; however, their meaning is left unexplained. The nearly complete silence is interrupted only by the natural sounds of the wind and birds chirping in the garden, and somewhere offscreen a person plays classical music on a piano as we slowly watch how sunlight creates shadows and reflects the light from leaves outside the windows on objects which come into and go out of focus - especially one important black-and-white photograph showing a couple in a warm embrace.

We only discover that the house belongs to the documentary maker himself when he enters the scene for the first time to answer a knock at the door. He asks for the name and address of the passer-by, who frequents his house asking for food. Agüero tells him he is making a documentary and points to the camera filming them right at that moment, so the visitor looks at us. Agüero asks the man if he can visit his house, and we assume the man had agreed when we later see Agüero placing a map on the wall with the name of the place where the visitor lives: Huechuraba. Agüero begins narrating in voice-over after 18 minutes, explaining that the 1945 photograph is the beginning of his story, and the couple in the photograph are his parents. 
The scene of memory takes place at 21.56 minutes, when the camera visits the Huechuraba neighbourhood. We expect to meet the visitor who had previously come to Agüero's house. Not finding him, the camera films the streets, particularly a couple of curious children who come to see what Agüero (off-screen) is doing. The scene concludes with the camera on the face of one of the children. It then cuts to a place we recognise as being in Agüero's home, focusing on a serigraph (a silkscreened artwork derived from photographs). Through montage, the camera moves across the artwork by the Chilean artist Eugenio Dittborn. Among the faces one can distinguish the image of a child of the indigenous Yagan community. We learn he was baptised as "Jimmy Button" by the English explorers who took him to England in 1830 to be "civilised". The immediate transition between the anonymous youngster in the street and the face of this Yagan child permits a clear observation of the continuation of that indigenous inheritance in today's Chilean phenotype, above all in the working class. The camera completes this sequence by moving slowly away from the artwork, towards the left, to find and linger on the cover of the book Darwin in Chile (1832-1835): Voyage of a Naturalist around the World.

This entire sequence is framed with Agüero's family members. The initial long focus is on the black-and-white photograph, only much later identified in voice-over as Agüero's father, in a sailor's uniform, with his mother. The purpose of the voice-over is to highlight how his father's experience in the naval institution influenced the whole family. Each person's experience with sailing is listed, including one of his father's sons, who, Agüero casually mentions, was tortured on a naval vessel during the dictatorship. The framing of the scene concludes with the visit Agüero receives from his children and grandchildren.

After returning to Huechuraba to complete the unfinished appointment from his previous visit, the sequence about the sea and Agüero's father is recommenced at 37.11 minutes, when Agüero introduces his son of 16 years, Raimundo, doing his homework in front of the computer. As the camera completes an expository tour through certain details of the house and the ornamental ships displayed on the furniture, Agüero's voiceover recalls the story that his father had told his children about the great tsunami of 1960 , and of the violence that gave it an unreal character.

Interjected in the scene is an intertextual dialogue, maintained throughout the film, with his 1992 documentary Sueños de hielo (Ice Dreams), in which Agüero had constructed, in the language of fiction, the movement of an ice floe which took place in the years of the first post-authoritarian government. In fact, the Chilean government had indeed ordered an iceberg shipped to Expo92 in Seville to represent the country as part of the Quincentennial Commemoration of the arrival of Columbus in the Caribbean.

As in the previous sequence, the scene is integrally constructed via montage, a juxtaposition of diverse elements that configures a visual mise en scène through a mixture of still camera and expositive style that provides a sort of domestic archive (De los Ríos and Donoso 2015, 64-67): family photos, a book about Jean-Luc Godard, DVD cases 
bearing the titles of some of Patricio Guzmán's films. Meanwhile, the autobiographic voice tells us:

At four years old, Raimundo was already dressed up in a navy uniform as Arturo Prat, the national hero. Now he is 16 , two years older than my father was when he entered the navy. Fourteen is how old Jimmy Button was when Captain Fitzroy kidnapped him and took him from Tierra del Fuego to England aboard the Beagle. Fourteen is how old Rosa was when she came from the countryside to work in my grandfather's house. When Jimmy Button returned home at the age of 16 aboard the Beagle, together with Darwin, he could speak English and his father had died. Rosa never went back home; she stayed forever in my grandfather's house, and never learned to read or write.

The story about Agüero's son serves as the nucleus around which the already suggested narrative traces are picked up again, serving at the same time to round out the fabric of stories about children and adolescents of various epochs and of various ethnic and social origins, a circle that has been opened with the child from the marginal township shown in the previous sequence.

In chronological order, the tour is initiated in 1830 when the English explore the Southern Cone. In the same way as they collect botanical and zoological specimens, they also capture the indigenous youth later baptised as Jimmy Button. The reference to Arturo Prat also situates Chile within the context of territorial aspirations; after the Pacific War that consecrates Prat as a national hero, Chile extends its frontiers to incorporate part of the Peruvian and Bolivian territory, depriving the latter of access to the sea. Rosa is presented as the maid in the grandfather's house, and the absence of her surname serves to clarify the virtually generic nature of the feudal model of domestic servitude that prevailed in Chile until the rise of the Responsible State. Although Agüero's father did not live long enough to experience the dictatorial period, and was therefore able to preserve his pride as a Navy officer, he did live to witness the earthquake and tsunami of May 1960. Raimundo, meanwhile, passes through adolescence and is educated with great care in the Chile of the transition, a period clearly established in the scene about the ice floe that travels to Seville.

If there is barbarity in capturing an indigenous youth to "civilise" him, or in depriving a young country girl of her family and of access to education, moving an enormous mass of ice through the southern seas in 1992 (destroying whole ecosystems in the process) is no less atrocious. The citing of such an event 20 years later becomes more dramatic in the face of the current accelerated destruction of icebergs by global warming. The image of magnificence projected by the iceberg contrasts with the fragility of the democracy of that time, but also with the present-day Chile, which has been subjected to 40 years of the consumer economy responsible for melting the age-old solidity of those mounds of ice.

The sea sequence concludes at 46.02 minutes, when the postman knocks at the door. This is a character Agüero will revisit in the following scene. The motif of the sea therefore functions to metaphorically structure the trajectory and destination of this 
sum of experiences and personal-collective stories. Among them, those that remain cloistered - "landlocked"- are the servant, Rosa, and Bolivia, deprived of access to the sea since 1879. The water in the ice floe is forced to make the journey across the northern seas, almost in the same manner as Jimmy Button who, in spite of returning, was never able to truly reintegrate back into his community. However, the water suspended in the ice also functions as a metaphor of arrested time, a simile of the traumatic obsession imposed by the dictatorship. The surface that is visible to the eye appears minimal in relation to the enormous mass hidden in its subterranean volume, which is comparable to the historical-political weight of the country. It is through the technique of montageassisted by a minimalist autobiographic voice-over situated in the cloister of the familiar, combining times, persons, circumstances, and spaces - that a collective "I" in the documentary voice is made possible. Or, as expressed by Deleuze (2005b, 33-34):

It is montage itself which constitutes the whole, and thus gives us the image of time. ... Time is necessarily an indirect representation, because it flows from the montage which links one movement-image to another. This is why the connection cannot be a simple juxtaposition: the whole is no more an addition than time is a succession of presents. ... precisely because it selects and coordinates "significant moments", montage has the property of "making the present past", of transforming our unstable and uncertain present into "a clear, stable and desirable past", in short, of achieving time. ... time as indirect representation that flows from the synthesis of images.

In the Chilean case analysed here, it is not so much about returning to "a clear, stable and desirable past", but rather about making such a past explain and give meaning to a dislocated present. This is how "achieving time" should be read as the desire for decompressing arrested time in order to permit it to flow. Therefore, "the significant moments", the events that El otro dia highlights in this montage, are those that permit us to observe the past in today's present, the real face of the popular social subject: from the abuse that turned a people into the disappeared through colonisation and expropriation of their lands and knowledge, journeying through the feudal use of villagers as household servants to the popular subject's destruction/disappearance in the times of dictatorship to arrive at the precarious present-day position. It is in this way that the montage structures an image-time, making a memory that becomes a reflection, or, as Deleuze says, citing Bergson, "this time-image extends naturally into a languageimage and a thought-image. What the past is to time, sense is to language and idea to thought" $(2005 \mathrm{~b}, 96)$. The sum of layers of time facilitate a journey to the interior that enables penetration of that cold density of time, metaphorically exposed in the ice floe, which permits the tracing also of a sort of circle between the abuses of First Nation peoples and the persistent and continued precariousness and social abuse of today's working class. 


\section{TIME-IMAGE AND THE ABJECT IN THE FAMILIAR}

The dictatorial moment suggested by the father's maritime influence on the family is revisited when Agüero's brother visits him. This scene dramatically blurs the borders between the sociopolitical and the private/family realms. As in the scene with his son, there are shots from Sueños de hielo, from the viewpoint aboard a ship, focusing on two enormous icebergs. The next shot focuses on birds drinking water in the garden of Agüero's house, until the doorbell rings:

Ignacio Agüero: One moment! [The camera takes Ignacio's viewpoint as he walks to answer the door.] Hi. Good day.

Felipe Agüero: Any news? ... There is not much light in here.

[Ignacio speaks from a different room, while the camera follows Felipe as he inspects the house and checks for food in the fridge and freezer.]

Ignacio Agüero: [In voice-over] That's Felipe, my twin brother. Whenever he comes, he does this.

[Felipe leaves the room. We hear the toilet flushing. He comes back into the room, chooses a book from the shelf and takes a seat.]

Ignacio Agüero: [While Felipe is reading, the camera closes in on his face. Agüero continues in voice-over.] People say that when a twin cuts his finger, it hurts the other twin as well. But that isn't true. When they tortured him in the National Stadium I didn't feel a thing. I only ever found out about it many years later. What would my father have said if he had known?

The fixed camera takes a number of medium and long shots to construct an everyday atmosphere that is legitimate based on the familiarity of the subject it documents: “... my twin brother. Whenever he comes he does this." Everything in this scene seems to suggest that what we will observe is the perfect blend of an image of time and space, given the fact that the artist not only shares his lifetime with his brother (the two ice floes in the opening scene), but also foresees each movement that his brother makes in the ultra-known space of his home - the kitchen, bathroom, sitting room - thereby offering a feeling of total normality and comfort in the everyday. Nevertheless, there is a certain denaturalisation in the creation of this scene given the marked interest in aestheticising this normality, something more appropriate to narrative cinema than documentary. On the one hand it is obvious there has been a direction of performance, since the brother has been guided in his movements through the house, a device rendered invisible due to the extremely careful editing of perfect cuts, giving a feeling of continuity and producing a scene of complex simplicity. Hence, in spite of the familiarity that effectively exists, the scene composition has demanded a process of editing and direction that is contradicted by the implicit spontaneity expected in the "normal" and everyday, which, until this moment, the documentary had achieved with painstaking care.

The information about the torture suffered by Agüero's brother is offered in a confidential tone, although deprived of emotion. We perceive, nevertheless, that it is treated only with a verbal distancing, since in the entire scene, it is the only moment in 
which the camera offers a close-up while the brother reads. Such closeness confronts the spectator with a face identical to that of the documentarist, so that the scene appears to deal more with the splitting of a single subject than the existence of two individuals, as in the speaking to the part of oneself that has remained unknown. Here we find two distinct individuals that look identical: one a victim of torture and the other exempt not just from the pain of such abuse but also - due to ignorance of the facts - deprived of participating in the experience to offer at least support and empathy in view of the pain suffered. Given that torture is an experience of abjection, it becomes an incommunicable experience, thus creating a gap in which the identical twin brothers, in spite of the unitary origin that defines them, now exist in ontologically distinct universes, in unspeakable and non-transferable spaces of experience: familiar, yet alienated from each other at the same time. Therefore, the close-up confronts us with a "direct time-image that always gives us access to that Proustian dimension where people and things occupy a place in time which is incommensurable with the one they have in space" (Deleuze 2005b, 37). We are therefore confronted with an intrinsic contradiction between that lost time (in the Proustian sense) - impenetrable, non-transferable, and non-communicable - and the false immediacy and accessibility that the close-up suggests to us. Since the director himself has not been able to feel nor share the suffering of his brother, the artistic gesture functions rather as a desire to achieve at least a level of intimacy and aesthetic closeness with the pain of the torture suffered by him. On the other hand, and beyond the filial relationship, the ontological distancing between the brothers can also be read as an allegory of the familial-national, of the enormous breach that separates those in the country who suffered torture, persecution, and death, and those who remained exempt from it. In that sense, the existential abyss between brothers of identical origin and appearance confronts us with two faces of the same coin. It is in this context that we are able to understand the careful editing of the scene as a possible symptom of insecurity, but at the same time of caution, in order to transmit an experience that, although coming from an intimate and familiar being, possesses limits that make it unavoidable and impenetrable. Thus, the attention to the aesthetic serves to make evident the ontological breach between the brothers, but also to leave evidence of the epistemological limits confronting art in transmitting abject experiences such as torture.

\section{ZOE, BIOS, AND THE PRECARIAT: TIME UNDER NEOLIBERALISM}

Although the autobiographical voice of El otro dia is retained in the domestic sphere, it makes of it a site of fluid borders where the narration is frequently interrupted, be it through laconic visuals of the living space itself, or - as we have already statedthrough the numerous habitual visitors who come calling: friends, family members, vendors, deliverymen, and beggars. It is through these multiple visitations that Agüero finds it appropriate to document the lives of his visitors as well. To follow through with 
the aesthetic style already established, the move of the director to their homes is not documented through a movement-image, but is traced on a map that draws together the transit points. This technique photographically and instantaneously permits an appreciation of the physical (and social) distances that separate them.

In fact, we could say that the visitors who call at the door literally come to call the attention of the artist, so that he can leave the self-absorption of memory and contemplation of that past and open the gaze to the present that moves through the streets. It functions also as a metaphor for the fact that the documentary about memory, which Agüero himself inaugurated in Chile with No olvidar, appears to have ignored the most immediate social emergency: the new forms of social suffering created by the market economy, which has made work, the natural environment, labour, and social relations precarious and has displaced the former popular social subject to the lowly place of the consumer.

This return to the social problematic seems to take place after the realisation that the central role once played by poverty as the most significant event denounced and documented by New Chilean Film has disappeared. This is not to say that poverty itself has been eradicated, but rather that the event of poverty has been superseded in Chile since the 1970s by the urgent need to denounce human rights abuses. The new forms of economic social abuse consolidated in the neoliberal era reside in what social scientists describe as precarious forms of labour, with economic growth achieved without a corresponding growth of equality. These discriminatory forms of "growth" accentuate and perpetuate the individualistic ethos subscribed to by the market economy, subverting a potential critique of these structures by weakening other areas of social cohesion. The result of this is an emerging class group that Guy Standing $(2011,8)$ describes as "the precariat":

The precariat could be described as a neologism that combines an adjective "precarious" and a related noun "proletariat". ... It consists of people who have minimal trust relationships with capital or the state, making it quite unlike the salariat. And it has none of the social contract relationships of the proletariat, whereby labour securities were provided in exchange for subordination and contingent loyalty, the unwritten deal underpinning welfare states.

In El otro dia, with the exception of the family members who visit the director, all those who knock at his door inscribe themselves to a major or minor degree within the category of the precariat. Two of them are the postman, Don René, and Señora Verónica Astorga, who periodically visits the director to ask him for food.

[Agüero visiting Don Rene's house:]

Don René: We live here next to a factory. They make poles. They make such a lot of noise. And they pollute a lot. ... But in the end you get used to it.

Agüero: Don René, how long have you been a postman?

Don René: I have been working with the Chilean post service for about 30 years.

Agüero: How long have you been coming to my house? 
Don René: About 11 years. I joined the distribution [department] because I thought I would have more time to study because I left university early. But I loved the job and got involved with it. I kept putting off my studies and never went back.

[Agüero at Señora Verónica's apartment:]

Agüero: Señora Verónica! [giving her a handshake]

Señora Verónica: Good afternoon. How can I help you?

[The camera shows a pan view of her neighbourhood and the apartment where she lives.]

Señora Verónica: [close-up shot] I live with my partner, and my daughter visits us sometimes. She is going through a difficult time, and she comes and stays with my grandchildren here at home. I rent this and I've got quite a few problems now, so I've been a bit absent.

Agüero: When you come to my house, do you go all the way from here, from your apartment?

Señora Verónica: Yes, I come from here.

Agüero: And where do you go?

Señora Verónica: I go to your house. I go to various houses like yours, where people have helped me for years. ... If I don't go out, I don't eat. My partner has been out of work for three months. ... This week he found a job because he is a master carpenter. ... We used to sell plastic things ... my partner is wonderful. We wanted to get married last month but we couldn't pay the rent and then they cut off the electricity ... we had no work.

The cases of Don René and Señora Verónica represent two examples of social and work precariousness in Chile. Don René works for Correos de Chile (the Chilean Postal Service), one of the few non-privatised state-owned enterprises, and as such he has had stable employment. This has allowed him to enjoy human contact and to establish prolonged relationships with the customers, and to nourish a great sense of loyalty to his job, since, as Standing $(2011,8)$ has indicated, "labour securities were provided in exchange for subordination and contingent loyalty." Nevertheless, the fact that he lives next to a factory making materials out of concrete indicates an essential lack of urban planning, which affects the quality of life and health of every family group. On the other hand, the fact that Don René was unable to conclude his university studies indicates that he is located within the middle-class precariat which, due to the privatisation of education and high fees, has meant that he has had to choose between working and studying. Due to the differences in salary between positions for non-qualified persons and those with a university education, not to have access to tertiary education implies an automatic reduction in economic possibilities.

Señora Verónica, however, finds herself in the even more precarious working conditions experienced by the Chilean proletariat. The total informality that has been imposed, above all in contracts of manual labour, affects not only basic subsistence, but also any possibility of establishing oneself. This makes long-term plans impossible to achieve (as Don René, on the other hand, had been able to do to a certain extent). Consequently, Señora Verónica has been unable to formalise the relationship with her partner, and she is in even less of a position to help still more vulnerable members of the family, such as her daughter and grandchildren. 
Taking account of the distinction that Agamben (1998) establishes between zoe (biological human life) and bios (the political co-existence of human beings), we are able to say that Don René, although he does not feel that his biological life is directly compromised, is clearly affected by the unhealthy conditions in which he lives. His ability to resolve the basic conditions of his well-being permits him at least to exercise his political existence, enjoy contact with others, reflect on and feel himself reconciled to the "options" in life he has taken: to abandon his studies in order to work. Nevertheless, when attempting to explain the environmental conditions in which he is living, he instead concedes that "you get used to it", suggesting his need to normalise undesirable and unacceptable conditions which at the same time relativises his condition of being a full "political being".

The extreme precariousness of Señora Verónica situates her, on the other hand, in an existence totally focused on sustaining her biological condition. She says, "If I don't go out, I don't eat," so she finds herself deprived of the ability to exercise her political self, not only because her time is totally dedicated to providing herself with sustenance, but also because in not forming part of any collective related to the world of work, she is excluded from the social. She declares: "I've been a bit absent," and she is unable to contain her tears in the face of the shame of not being able to offer her grandchildren a meal. Although her partner can count on sporadic work, such discontinuity does not permit him to form ties or union alliances. Moreover, facing such precarious conditions, any form of questioning or rebellion against the now-normalised system might deprive him of finding work. This situation both develops submission and strengthens the status quo, to the point that such conditions become the norm and translate the responsibility for unemployment onto the worker himself, and not onto the system that structures these conditions. Such is the manner in which the neoliberal society of today exercises control and coercion over its citizens: not in manifest physical exploitation, but through the language of "flexibility" and "individual" opportunities that have made working conditions precarious. This state of affairs affects physical survival, but also, and above all, the status of citizenship by undermining the proletariat's condition as actors and architects of the social processes in which they live.

The autobiographical, anti-monumental voice articulated by the technique of time-image permits El otro día to develop an intimist vision of the uneventful face of neoliberal precariousness in Chile, and it does so from the collective "I" forged by the cinema of memory. It is in this way that the time of unemployment (the lack of activity) and the time of work precariety (where the person lives $100 \%$ subjected to conditions of survival) coexist with time saturated in ultra-activity, "productivity" for consumption without limits. In this context, nothing seems to go more against the ethos of neoliberalism than time dedicated to memory and reflection, to the extent that both activities distance themselves from the pragmatic value of time dedicated exclusively to the pursuit of subsistence $(z o \bar{e})$. On the other hand, both memory and reflection do make it possible to exercise citizenship (bios), responding through these means to the social 
rupture threatened and engendered by precariat society. In this sense, contemplation of the social from a space belonging to the domestic and quotidian makes the artist a participant witness that denormalises the instrumental logic of neoliberalism.

\section{ACKNOWLEDGEMENTS}

I am thankful to my colleagues Gwyn Fox and Kathryn Leman, and to Camilo Diaz Pino for assisting me with the translation from Spanish into English.

\section{REFERENCES}

Agamben, G. 1998. Homo Sacer. Sovereign Power and Bare Life. Translated by D. Heller-Roazen. Stanford, CA: Stanford University Press.

Arenillas, M. G., and M. Lazzara, eds. 2016. Latin American Documentary Film in the New Millennium. New York: Palgrave Macmillan.

Beck, U., and E. Beck-Gernsheim. 2000. Individualization: Institutionalized Individualism and Its Social and Political Consequences. London: Sage.

Bossy, M., and C. Vergara. 2010. Documentales autobiográficos chilenos. Consejo Nacional de la Cultura y las Artes, Fondo Audiovisual. Accessed November 21, 2017. http://www.documentalesautobiograficos.cl/.

Corro, P., C. Larraín, M. Alberdi, and C. van Diest. 2007. Teorías del cine documental chileno: 1957-1973. Santiago de Chile: Pontificia Universidad Católica de Chile.

Deleuze, G. 2005a. Cinema 1: The Movement-Image. Translated by H. Tomlinson and R. Galeta. London: Continuum.

Deleuze, G. 2005b. Cinema 2: The Time-Image. Translated by H. Tomlinson and R. Galeta. London: Continuum.

De los Ríos, V., and C. Donoso. 2015. El cine de Ignacio Agüero. El documental como la lectura de un espacio. Santiago de Chile: Editorial Cuarto Propio.

Escobar Arellano, C. 2012. "Documentales autobiográficos de la memoria. El caso de dos realizaciones nacionales contemporáneas." Sangría. Accessed November 21, 2017.

http://sangria.cl/2012/10/critica-documentales-autobiograficos-de-la-memoria/.

Harvey, D. 2005. A Brief History of Neoliberalism. Oxford: Oxford University Press.

Lebow, A. 2012. The Cinema of Me: The Self and Subjectivity in First Person Documentary. London: Wallflower Press.

Lyotard, J-F. 1984, The Postmodern Condition: A Report on Knowledge. Minneapolis: University of Minnesota Press. 
Nancy, J-L. 1996. Être singulier pluriel. Paris: Éditions Galilée.

Nancy, J-L. 2000. Being Singular Plural. Translated by R. D. Richardson and A. E. O’Byrne. Stanford, CA: Stanford University Press.

Navarro, V., and J. C. Rodríguez, eds. 2014. Global Cinema: New Documentaries in Latin America. New York: Palgrave Macmillan. https://doi.org/10.1057/9781137291349.

Nichols, B. 2001. Introduction to Documentary. Bloomington: Indiana University Press.

Piedras, P. 2014. El cine documental en primera persona. Buenos Aires: Paidós.

Pino-Ojeda, W. 2013. "Forensic Memory, Responsibility, and Judgment: The Chilean Documentary in the Post-authoritarian Era." Latin American Perspectives 40 (1): 170-86. https://doi.org/10.1177/0094582X12463198.

Salazar, G., and J. Pinto. 1999. Historia contemporánea de Chile II: Actores, identidad y movimiento. Santiago de Chile: LOM.

Salinas Muñoz, C., and H. Stange Marcus. 2008. Historia del cine experimental de la universidad de Chile 1957-1973. Santiago de Chile: Uqbar Editores.

Santa Cruz G., J. M. n.d. "Transmutaciones del cuerpo: Dictadura y documental autobiográfico contemporáneo." Cine Chile: Enciclopedia del cine chileno. Accessed November 21, 2017. http://www.cinechile.cl/crit\&estud-305.

Standing, G. 2011. The Precariat: The New Dangerous Class. London: Bloomsbury Academic.

Vega, A. 2006. Itinerario del cine documental chileno: 1900-1990. Santiago de Chile: Universidad Alberto Hurtado.

\section{FILMOGRAPHY}

Agüero, I., dir. No olvidar. 1982. Grupo Memoria-Aida. 30 mins.

Agüero, I., dir. Como me da la gana. 1985. Prod. Ignacio Agüero. 30 mins.

Agüero, I., dir. Sueños de hielo. 1993. Ignacio Agüero and Andrés Racz. La Mar Films. 56 mins.

Agüero, I., dir. El diario de Agustín. 2008. Ignacio Agüero Asociado/Amazonía Films. 80 mins.

Agüero, I., dir. El otro día. 2012. Ignacio Agüero Asociado. 122 mins.

Agüero, I., dir. Como me da la gana II. 2016. Ignacio Agüero \& Asociados. 86 mins. 